\title{
ATSAKOMYBÉS SUBJEKTO STEIGTIS TECHNIKOS AMŽIUJE: HANSAS JONAS IR BRUNO LATOURAS
}

\author{
Lietuvos kultūros tyrimu institutas \\ Saltoniškių g. 58, LT-08105 Vilnius \\ Tel. (8 5) 2752857 \\ El. paštas: baceviciute@gmail.com
}

Straipsnyje oponuojama bandymams antropoceno tyrimuose etinę problematiką išstumti i paraštes ir ginti technosferos autonomijos tezę. Nurodoma, jog apeinant etinès perspektyvos ir atsakomybės klausimą, techninė žmogaus veikla ir jos pėdsakas yra natūralizuojami, o etinis sprendimas paverčiamas techniniu sprendimu. Pasitelkus dviejų technikos filosofų - Hanso Jonaso ir Bruno Latouro - pozicijas, siekiama apmąstyti, kaip techninè mediacija dalyvauja atsakomybès subjekto steigtyje, kaip ji ịtarpina globalios ir lokalios perspektyvų ịtampą. Parodoma, jog Jonaso atsakomybės subjektą steigianti „baimės euristikos“ praktika kreipia ị sąmoningą askezę ir kolektyvinę techninès galios kontrolę, tuo tarpu Latouras atveria galimybę kalbèti apie hibridinių subjektų daugio pasidalintą veikimą, kuriame etinis sprendimas jau „užterštas“ techninio sprendimo, o techninis sprendimas išlaiko etinio sprendimo pèdsaką. Straipsnyje pateikiamas taromatų sistemos pavyzdys, kuriuo siekiama parodyti, kaip etinė motyvacija gali būti "irašyta" technikos medijoje, t. y., kaip akumuliuojantis technikos efektas, susiejantis lokalią ir globalią perspektyvas, yra panaudojamas gamtosaugos tikslais.

RAKTAŽODŽIAI: antropocenas, techninè mediacija, atsakomybė, kvazi-subjektas, kvazi-objektas, Hansas Jonas, Bruno Latouras. 
Pastaruosius penkis dešimtmečius filosofų darbuose etinis technikos aspektas gana intensyviai diskutuojamas, o tyrimai iš esmès plètojami dviem kryptimis: orientuojamasi ị etinius klausimus, kuriuos kelia konkreti technologija (dažniausiai ịvairios skaitmeninès technologijos) arba ị tai, kaip naujos techninès galios verčia permąstyti tradicinius etinius klausimus. Šiame straipsnyje iš esmés judame antrąja kryptimi - etinio technikos aspekto svarstymus sukonkretiname $\mathfrak{i}$ atsakomybės subjekto steigties problemą, kurią nagrinèjame akcentuodami ne vieną ar kitą techninio medijavimo rūšì, o globalų techninès galios poveiki planetos ekosistemai. I techniką žvelgiame kaip ị planetos masto fenomeną, tad čia pateikiami apmąstymai atliepia problematiką, kurią Pieteris Lemmensas, Vincentas Blokas ir Jochemas Zwieras siūlo vadinti „žemiškuoju posūkiu“ technikos filosofijoje, susijusiu su antropocenu kaip nauja sąlyga, skatinančia neapsiriboti mikro lygmens analizèmis, dominavusiomis ,empirinio posūkio“ technikos filosofijoje (Lemmens, Blok, Zwier 2017: 123; taip pat plg. Lemmens, Van Den Eede 2021).

Tačiau iš pat pradžių reikia pasakyti, kad antropoceno tyrimuose, nukreiptuose ị makro lygmeni, pati etinio subjekto steigties problema tampa dviprasmiška ir nepaprastai komplikuota. Pirma, tai susiję su antropoceno epochos apibrèžimu iš skirtingų perspektyvų - „planetos perspektyvos“ ir „žmogaus perspektyvos“. Planetos perspektyvoje turime reikalą su „stratigrafų antropocenu“, geologine epocha, kurioje žmonija pasirodo kaip nauja geologinè jèga, tuo tarpu žmogaus perspektyva neatsiejama nuo techninės galios sukeliamų pasekmių, kurios svarstomos moralès ir politikos lauke. Istorikas ir postkolonializmo teoretikas Dipeshas Chakrabarty, išsamiame apžvalginiame straipsnyje „Antropoceno laikas“ išryškindamas su antropocenu susijusias kontroversijas, akcentuoja šių dviejų perspektyvų nesuderinamumą: „[...] buvimo būdas, kuriuo žmonès gali kolektyviai veikti kaip geologinè jèga, nèra buvimo būdas, kuriuo žmonès - individualiai ar kolektyviai gali ịsisąmoninti esą tokia jèga" (Chakrabarty 2018: 28). Matyt, todèl nemaža dalis tyrèjų, pavyzdžiui, viešosios etikos profesorius Clive’as Hamiltonas, mokslo istorikas Christophe'as Bonneuilis, aplinkos geopolitikos ir migracijos dinamikos tyrèjas François Gemenne’as ir kiti, pabrèždami antropoceno specifiką, renkasi „planetos perspektyvą "ir teigia, jog apskritai nedera tokio milžiniško masto ịvykio kaip antropocenas interpretuoti etikos terminais, mat šitokia interpretacija ji normalizuotų, subanalintų, paverstų dar viena „aplinkosaugos problema“, tad kur kas tiksliau sakyti, kad antropoceno iššūkis pranoksta etinę perspektyvą (Hamilton, Bonneuil, Gemenne 2015: 8; Hamilton 2015). Pripažindami makro lygmens analizės specifiką ir mokslininkų norą pabréťti antropoceno epochos išskirtinumą, vis dèlto manome, kad įtampa tarp globalios ir lokalios perspektyvų turètų būti išlaikyta, o 
techninè žmogaus veikla ir jos pėdsakas neturètų būti natūralizuojami nustumiant ị šalị „žmogaus perspektyvą“, o su ja ir mūsų atsakomybès klausimą ${ }^{1}$.

Tam tikra technikos natūralizavimo tendencija, kuriai siekiame oponuoti, yra pastebima amerikiečių geologo ir aplinkos mokslininko Peterio K. Haffo straipsnyje „Technika kaip geologinis fenomenas: implikacijos žmogaus gerovei“. Šis mokslininkas ị techniką sakosi žvelgiąs „iš išorès“, ne antropocentriniu požiūriu, nurodydamas, jog globaliu mastu technika turètų būti suvokiama kaip technosfera (matant jos panašumą i ankstesnes geologines paradigmas - litosferą, atmosferą, hidrosferą ir biosferą), t. y. kaip autonominė sistema, turinti ne tik sunaudoti didelius energijos išteklius, bet ir išvystyti šiuo metu jos stokojamą gebejjimą perdirbti savo pačios atliekų srautą. Nors Haffas ir pripažįsta, kad technosfera yra pirmoji geologinè paradigma, pakankamai sudetinga, kad per savo žmogiškąją dedamąją suvoktų kitų paradigmų paramą jos pačios egzistavimui (Haff 2014: 304), jis akcentuoja ne saugos, o energijos kiekio didinimo svarbą. Pasak jo, klimato kaitos problemą technikos fenomenas reikalauja spręsti ne mažinant energijos suvartojimą, bet, priešingai, ji didinant - taip rastųsi užtektinai energijos perdirbti atliekų srautui: pavyzdžiui, energijos kiekiai galètų būti didinami ne tik naudojant saulès energiją kaip atsinaujinantị šaltinị, bet ir išgaunant energiją kosmose bei siunčiant ją mikrobangomis i Žemę (Haff 2014: 307-308).

Pastarasis požiūris leidžia apibrèžti antrąji sunkumą. Jis susijęs su tuo, kad techninè žmogaus veiklos mediacija grasina pasirodyti kaip tokia, kurios metu etinè problema paverčiama technine, o žmogiškoji perspektyva ištirpinama technikos medijoje nè neužklausiant tokios modifikacijos pobūdžio. Nebelieka globalios (planetos) ir lokalios (žmogiškos) perspektyvų ịtampos, jos abi susilieja techniniame sprendime, o tai sukuria iliuziją, jog nebeturime reflektuoti savo elgesio gamtos ir kitų būtybių atžvilgiu, mums tereikia rasti tinkamą techninị sprendimą, kuris leistų išspręsti globaliu mastu kylančias problemas, kaip antai klimato kaita, ozono skylè, dirvožemio dykumejjimas ar plastiko tarša. Taigi tariama, kad žmogiškoji atsakomybẻ ir etika čia pasibaigia. Visgi mes laikomès požiūrio, jog natūralizuodami tech-

\footnotetext{
1 Antropoceno problematikos kontekste paminètinas ir kitas būdas mąstyti globalios ir lokalios perspektyvų santykị akcentuojant ne tiek atsakomybès subjekto steigties problemą, į kurią susitelkiama šiame straipsnyje, kiek ontologinę prieigą - techninę gyvenimo formą. Čia priskirtinas Bernardo Stieglerio bandymas Antropoceno diskursui priešpriešinti lokalumą ir naują kosmologiją (Stiegler 2018) bei Yuk Hui pastanga kalbèti apie kosmotechnikas (daugiskaita) ir jų steigiamą kosminès tvarkos ir moralès ryšį (Hui 2021). Pastarasis autorius permąsto Martino Heideggerio technikos interpretaciją ir technikos klausimą formuluoja kaip vietos, lokalumo klausimą, taip siekdamas išeiti anapus modernios technikos keliamo pavojaus kibernetizuoti planetą ir kolonizuoti visatą. Hui knygoje Technikos klausimas Kinijoje. Esè kosmotechnikos tema siekia rekonstruoti Kinijos technikos filosofiją ir itvirtinti technikos sąvokos pliuralumą (Hui 2016). Ši Hui nuostata yra artima straipsnyje analizuojamam Bruno Latouro pliuralistiniam požiūriui į techniką.
} 
niką ir skelbdami technosferos autonomijos tezę, ne išsprendžiame, o paneigiame problemą, nes atsisakome reflektuoti savo pačių perspektyvą arba redukuojame ją iki techninio sprendimo. Todèl manome, kad yra reikalinga labiau moderuota prieiga, leisianti atidžiau panagrinèti, kaip techninè mediacija dalyvauja atsakomybès subjekto steigtyje, kaip ji ittarpina globalios ir lokalios perspektyvu ittampą.

Keliame hipotezę, kad technologijos ịtarpina ne tik mūsų veiksmus, bet ir mūsų motyvus ar veikimo priežastis, vadinasi, turime apmąstyti ne tik technologiju medijavimą nekontroliuojamų veiksmo padarinių prasme, bet ir patị mūsų veikimo motyvų medijavimą, t. y. etinio subjekto steigties medijavimąa ${ }^{2}$ Juk galiausiai prisiimame atsakomybę tik tada, kai aktualizuojame savyje pasirinkimo ir praktinio svarstymo gebą.

Atsakomybės subjekto steigties problemą analizuosime daugiausia atsiremdami ị dviejų technikos filosofų - Hanso Jonaso ir Bruno Latouro - apmąstymus, kuriuose įžvelgiame pastangą reflektuoti ir kritiškai peržiūrèti modernybès palikimą bei iš naujo aktualizuoti atsakomybès klausimą. Būdami dèmesingi technikos fenomenui, abu filosofai mégina atskleisti pakitusias atsakingo veikimo galimybès salygas.

\section{Technikos mediacija: nuo veiksmų padarinių prie motyvų}

Hansas Jonas, vienas pirmųjų paskelbęs, kad šiuolaikiniame globaliame pasaulyje technika liovėsi buvusi etiškai neutrali ir reikalauja mūsų atsakomybès, sykiu nurodè ir du esminius iššūkius atsakomybès subjekto konstitucijai.

Pirmasis iššñkis - negalejimas kontroliuoti techninio veikimo padarinių susijęs su tuo, jog technikos raida paverte žmogaus veikimą kumuliatyviu ir šio veikimo skalè bei mastas išsipletė ir padidejjo tiek, kad neišvengiamai sukelia toli siekiančius ilgalaikius padarinius. Reikia paminèti, kad technikos ịtarpinto veikimo kumuliatyvumą tyrinėjo ir daugybė vèlesnių mąstytojų, išryškindami skirtingus šio

\footnotetext{
Tyrimų, analizuojančių atsakomybės subjekto problemą technikos amžiuje ir diagnozuojančiu nerimą keliantị desubjektyvacijos procesą, yra nemažai. Vis dèlto ị tolesnę analizę neįtrauksime tyrimų, fiksuojančių atsakomybès subjekto krizę antropoceno epochoje, bet techninės mediacijos problemą išaknijančių vartotojiškame kapitalizme. Pastarieji tyrimai remiasi kompleksine technikos medijavimo (daugiausia skaitmeninių technologijų), vartotojiško kapitalizmo ir geismo analize. Kaip pavyzdi galetume nurodyti Helena'os De Preester straipsnį, kuriame kalbama apie interpasyvumą ir iliuzijas be savininkų, kurios lemia žinojimo atsiejimą nuo veiksmo, o galiausiai veda į susidvejinimą arba atvirą cinizmą. Pasak De Preester, „[p]radoksaliu būdu ekologinis sąmoningumas nelemia vartojimo sumažejjimo. Priešingai, malonumo neteikianti panieka sau dèl uždrausto vartojimo malonumo veda ị tolesnị ambivalentišką vartojimą“, kai sakome "puikiai žinau, bet vis tiek..." (Preester 2021). Pripažindami minètos kompleksinès prieigos vertingumą, mes savo ruožtu susiauriname analizès lauką susitelkdami tik $\mathfrak{i}$ tai, kaip technika medijuoja atsakomybès subjekto steigtị, manydami, kad toks apribojimas leis aptikti pozityvesnes praktikas.
} 
fenomeno aspektus: vokiečių sociologas Ulrichas Beckas šị technikos medijuojamą veikimo efektą pavadino „erdviniu-laikiniu plyšiu tarp veiksmų ir jų poveikio“ (Beck 2000: 220), nes dažnai veiksmų poveikis išryškejja po daugelio metų, iki tol jis nèra pastebimas; aplinkos filosofas Timothy Clarkas diagnozavo lokalaus, betarpiško veiksmo krizę, mat galiausiai grèsmė kyla ne iš paties veiksmo, $\mathrm{o}$ iš nenuspejjamo tokių veiksmų daugybės akumuliuojamo poveikio. Pasak jo, kasdienio pasiturimo gyvenimo būdo Prancūzijoje padariniai jau ịsibrauna ị Bangladešo ūkininko gyvenamą erdvę didžiulių potvynių pavidalu (Clark 2012: 155).

Antrasis iššūkis - atsakomybès subjekto neapibrèžtumas. Kolektyvinis technikos įtarpintas veikimas palieka mus nežinioje, kai imame kelti klausimą apie atsakomybę už tokio veikimo padarinius; mat visiškai neaišku, kas yra šio kolektyvinio veikejjo "mes" - anoniminis kolektyvinis veikejjas, mokslininkai ekspertai, technologijų kūrèjai, viešoji valdžia ar „galingieji“?

Kaip matome, akumuliuojanti poveikị turintis globalios technikos fenomenas tradicinę, su asmens tiesioginiu veikimu ribotame laiko ir erdvès horizonte susijusią atsakomybès sampratą padaro bejẻgę, negalinčią atrakinti ir etiškai ịprasminti pasikeitusio žmogaus veikimo pobūdžio. Bandydamas atliepti į šiuos technikos amžiaus iššǔkius, Jonas nutaria eiti toliau Immanuelio Kanto pramintu keliu ir formuluoja atsakomybès imperatyvą technikos amžiui - „Elkis taip, kad tavo veikimo padariniai būtų suderinami su tikro žmogiško gyvenimo Žemeje tąsa“, arba „Elkis taip, kad tavo veikimo padariniai nesugriautų tokio gyvenimo ateities galimybès“ (Jonas 1984: 11). Kaip matome, Jonaso imperatyvas kreipiasi $\mathfrak{i}$ mus (kiekvieną) kaip potencialų atsakomybės subjektą bei ịtraukia ateities dẻmenị, leidžiantị mums suvokti techninio veikimo padarinių mastą. Tačiau, nors ir modifikuotas, šis imperatyvas lieka gana abstraktus, tad Jonas susiduria su panašiomis problemomis kaip ir Kantas: kaip susieti bendrą imperatyvo formuluotę su konkretaus žmogaus isipareigojimu ir veikimu?

Vienas iš būdų, kuriais Kantas mėgino spręsti šią problemą, - pasitelkti dinaminio gamtos didingumo patirtị, kurioje griaunamojo gamtos gaivalo didingumas rezonuodamas igalina mus atskleisti savo sieloje kitą - moralès - didingumą, suteikia ryžto ir padeda įsisąmoninti savo moralinę paskirti (Kantas 1991: 114). Kanto minties tęsinị (tik jau reflektuojant šiuolaikinės technikos fenomeną) galima atpažinti Kanto didingumo sampratos tyrinètojo Scotto R. Stroudo (Stroud 2003: 47-67) pastangoje ieškoti analogiškos atsakomybès subjekto steigties patirties, gamtos didingumo patirtị papildant ar pakeičiant technikos didingumu. Jis cituoja Robertą J. Liftoną ir Ericą Marcuseną, kurie taip apibendrina JAV Los Alamos nacionalinès laboratorijos mokslininkų reakciją i pirmąji branduolinio ginklo detonavimą $1945 \mathrm{~m}$. liepos $16 \mathrm{~d}$.: 
Emilio Segrè nurode ị pagarbios baimès jausmą („buvau didžiai sukrèstas naujo reginio“), sumišusị su ịkyriu pasaulio pabaigos vaizdiniu („Manau, akimirką man atrodè, kad sprogimas gali padegti atmosferą ir pribaigti žemę...“). Kennethas Bainbridge’as išreiškė baimès ir savęs pasmerkimo jausmą, kai kalbèjo apie nepamirštamai „šlykštų ir bauginantị reginị,“ ir paskelbè: „Dabar visi esame kalès vaikai.“ Juliaus Roberto Oppenheimerio [fiziko teoretiko, vadinamo „atominès bombos tèvu“] vaizdingame posakyje, pasiskolintame iš Bhagavad Gita’os, - „Dabar aš tapau mirtimi, pasaulių griovejju“ - slypi siaubas, kiek pridengtas literatūrinès-mitologinės išraiškos. I. I. Rabi aprašè ji persmelkusị „šiurpą“ suvokus „savo medinio namo Kembridže, laboratorijos Niujorke ir daugybės milijonų žmonių, gyvenančių netoliese“, trapumą (Lifton, Markusen 1991: 61).

Tiesa, priešingai nei Kanto akistatoje su gamtiškuoju gaivalu, čia pažadinama ne moralumo didybè, o siaubo persmelkta atsakomybès ir kaltės patirtis. Žinoma, kyla klausimas, ar branduolinio ginklo kūrime dalyvavę mokslininkai iki tol nepajègè îsisąmoninti savo veiksmų pobūdžio bei jų pasekmių, ir tik sprogimo metu patirtas sukrètimas pakeitè jų nuostatas ${ }^{3}$. Tačiau kol kas šị klausimą paliekame atvirą.

Grịžtant prie Hanso Jonaso, atrodo, kad tiesmukas technikos medijavimas, kai kalbama apie atsakomybès subjekto steigti, jam menkai terūpi. Griaunamoji technikos galia, „apreiškusi“ atominès bombos kūrèjams jų sukurto ginklo grèsmę, kaip ir Jonaso laikais gana paplitęs apokaliptinio technikos potencialo koncentravimas i atominę bombą, šiam filosofui neatrodo pakankamas. Jị domina daug platesnio masto pokytis. Todèl neatsitiktinai Jonasui atsakomybės subjekto steigtyje svarbu vaidmenị ima vaidinti „baimès euristika“, tačiau ne baimé apskritai ar atominès bombos baimè konkrečiai, o dvasinis baimès aspektas, padarantis ją mūsų sąmoningos nuostatos dalimi ir igalintis keisti mūsų kasdienes praktikas. Tad baimių priešakyje jis mato ne staigaus atominès bombos sukelto sugriovimo grèsmę, o lètą bendros tolydžios techninès civilizacijos raidos, su jos ịvairaus pobūdžio pertekliumi (gyventojų pertekliumi, pertekline tarša, pertekliniu planetos nualinimu), keliamą grèsmę (Jonas 1984: 202). Kadangi ši grèsmé sutelkta ne ị vieną ìvykį, kaip anksčiau cituoto Los Alamos poligone įvykdyto branduolinio ginklo bandymo atveju, bet yra ištirpusi bendroje techninès civilizacijos raidos tendencijoje, tad ir atsakas i ją nèra pavienis sprendimas, o persmelkia visą spektrą sprendimų nuo nuostatos formavimo (pavyzdžiui, paminètinas Jonaso priešinimasis genetinei inžinerijai) iki kasdienès praktikos keitimo. Nors Jonas ir nenurodo konkrečių praktikų pavyzdžių, sekdami jo mintị galime spèti, kad čia patektų ịvairaus pobūdžio vartoji-

3 Po II pasaulinio karo Oppenheimeris, tapęs JAV atominès energijos komisijos sudètyje veikusio Bendrojo patariamojo komiteto vadovu, siekè branduolinés galios kontrolès, priešinosi vandenilinès bombos kūrimui ir pan. Panašus virsmas XX a. 5 dešimtmečio pabaigoje pastebimas ir sovietų mokslininko Andrejaus Sacharovo atveju. 
mo praktikos, kurias esame kviečiami permąstyti ir eiti link, pavyzdžiui, sąmoningo apsipirkimo, sąmoningo keliavimo ir pan. Kaip matome, Jonasui yra svarbus pats refleksijos momentas, tiksliau - mūsų savirefleksija santykyje su kitu.

Čia turime prisiminti, kad anksčiau cituotas Jonaso atsakomybès imperatyvas pabrèžè ateities dẻmenị - mūsų rūpesčiu turi tapti ateities žmonių kartos ir jų gyvenimo kokybė. Tai reiškia, kad ateitis turi pasirodyti ne kaip mūsų kuriamų techninių projektų horizontas ar utopija, išreiškianti mūsų pastangas kolonizuoti, „uždaryti“ ateiti (plg. Peterio K. Haffo technosferos autonomijos tezę, stebètinai sutampančią su energetinio kosmoso kolonizavimo nuostata, būdinga ekomodernistinei strategijai), o kaip ateitis, kurioje paliekame vietos kitam.

Taigi matome galimybę Jonaso mintị interpretuoti dviem kryptimis: techninès galios kontroles kryptimi ir tarpgeneracinès etikos plètojimo kryptimi.

Jonas tikrai daug demesio skiria technikos galios kontrolès problemai. Pasak jo, „[ž]inojimas ir galia yra kolektyviniai, tad ir jų kontrolè turi būti kolektyvinè: ji gali kilti iš viešojo sektoriaus viduje veikiančių jègu" (Jonas 1996: 109). Tiesa, Jonas nekonkretizuoja viešos kolektyvinès kontrolès iggyvendinimo būdų. Jo atsakomybès etikai svarbi įtampa tarp asmeninio pokyčio (lokalaus dèmens) ir kolektyvinio veikimo (globalaus dèmens). Manytume, kad jo deklaruotos viešos kolektyvinès kontrolès ịgyvendinimą galima į̌̌velgti Ulricho Becko siūlomuose procedūriniuose sprendimuose, skirtuose kolektyvinių institucijų ịveiksminimui: 1) veiksmų pasekmès turi būti viešai diskutuojamos prieš priimant sprendimus, kurie jas sukeltų; 2) kaltininkai turi būti priversti ̣̂rodyti, kad jų gaminiai nepavojingi; 3) stipriausi pagalbininkai iš technokratų turi būti mobilizuoti ir patraukti gyvybès bei ateities pusėn; 4) reikalingas galių pasidalijimas tarp tyrimų ir jų pritaikymo, tarp rizikų diagnozės ir terapinių saugumo priemonių (Beck 1995: 170-171, 178) ir t. t. Kaip matome, Becko siūlomi sprendimai bent jau iš dalies yra vadybiniai, jais siekiama pagerinti institucijų veikimą, o klausimas apie individualų atsakomybès subjektą (užimantị svarbų vaidmenị Jonaso filosofijoje), regis, išbraukiamas iš darbotvarkès. Ir Beckas tam turi svarų motyvą. Pasak jo, individas visada yra atskirtas nuo sprendimų konteksto ir yra vien rizikos gavejas:

Kad ir kas išjudina riziką ir paverčia ją neapskaičiuojama, kad ir kas provokuoja institucinę krizę valdančio režimo ir rinkų lygmenyje, perkelia galutinę sprendimo atsakomybę individams, kurie galiausiai paliekami su jų pačių priemonėmis, jų pačių daliniu ir šališku žinojimu, su neišsprendžiamumu ir daugybe netikrumo lygmenų (Beck 2009: 195).

Nepaisant šio skirtumo, Jonaso ir Becko pozicijas vienija įsitikinimas, kad būtent kolektyvinè techninès galios kontrolè turi apsaugoti potencialius rizikos ga- 
vejjus. Tačiau potencialūs rizikos gavejjai yra ne vien dabar gyvenantys žmonės, bet ir ateities kartos. Tad būtina atskirai aptarti atsakingo veiksmo sampratos tarpgeneracinị pobūdị.

Remdamasis tèviškos atsakomybès, kaip asimetriškos atsakomybès už bejègio vaiko gerovę, paradigma, Jonas asimetriškos atsakomybès santyki perkelia i santyki su ateities kartomis (Jonas 1984: 130-135). Jų gerovè ar netgi egzistencijos galimybė priklauso nuo to, ar mes gebėsime apriboti savajji gerovès troškimą. Italu filosofé Tiziana Andina, papildydama Jonaso mintį, nurodo, kad ateities žmonių kartos gali pasirodyti ne tik kaip potencialūs rizikos gavejjai - technologijos numato ir kartų bendradarbiavimą (Andina 2018: 369). Vis dèlto toks bendradarbiavimas lieka gana dviprasmiškas, nes remiasi fikciniu ateities subjekto pobūdžiu (šis negali išreikšti jokio sutikimo dabar priimamo sprendimo atžvilgiu). Kaip pavyzdį Andina pateikia masinès iškastinio kuro gavybos veiksmą, turintį užtikrinti besivystančios šalies ilgalaikio aprūpinimo elektra poreikị. Italų filosofès teigimu, dèl sudètingos šiai veiklai reikalingos techninès infrastruktūros poreikio daroma prielaida, kad ir ateities kartos pletos šį veiksmą panašia linkme, t. y. pritars veiksmams, kurių reikia imtis ịgyvendinant ši sprendimą (Andina 2021: 329-330). Tačiau tikrovèje gali nutikti kitaip - nauja karta gali nepritarti šiam sprendimui ir orientuotis, pavyzdžiui, $\mathfrak{i}$ atsinaujinančią energetiką. Todèl net ir numanant bendradarbiavimą, atsakomybė lieka asimetriška, priklauso aktualiam sprendimo priemejui.

Sykiu Andina siekia modifikuoti tarpgeneracinị atsakomybès pobūdį užklausdama dvi Jonaso poziciją grindžiančias prielaidas: numatomumą ateities, kurioje iškyla grèsmè žmonių ir kitų būtybių egzistencijai, ir būtinybę apriboti savo gerovès troškimą. Galima sakyti, kad priskirdama Jonasui ateities numatomumo prielaidą, Andina pamatinị ontologinị klausimą „kodèl yra kažkas, o ne priešingai - niekas, juk galètų ir nebūti?"“, grindžiantị Jonaso atsakomybès imperatyvą ir jo rūpestị būties sauga, išverčia ị socialinės ontologijos plotmę, kurioje jam priskiriama pretenzija numatyti ateitị, tiksliau, projektuoti apokaliptinę jos versiją. Tačiau, mūsų manymu, kritikuodama pirmajją, ir ypač antrąją, Jonaso poziciją grindžiančias prielaidas, Andina priartẻja prie etinès plotmès ribos, jos deklaruojamas perèjimas nuo etikos lygmens prie socialinės ontologijos lygmens turi ir tam tikrų šalutinių pasekmių: taip nuo etinio sprendimo judama prie techninio sprendimo. Italų filosofès teigimu, pasirinkdami tvarią alternatyvą iškastiniam kurui - atsinaujinančią saulès, vejjo ir vandens energiją - neturime apriboti savo gerovès troškimo ar rinktis blogesnę gyvenimo kokybę bei atsisakyti pažangos (Andina 2018: 370), nes naujosios technologijos užtikrina tiek tvarumo, tiek gerovès principų igyvendinimą. Tuo tarpu mums atrodo abejotina, jog galima būtu apsieiti be vartotojiškos nuostatos keitimo. Ieškodami vien techninio sprendimo, paslepiame etinị sprendimą, suponuojantị ịvairių 
motyvų tarpusavio sąveikos keliamus klausimus. Kuo remdamiesi rinksimès vieną, o ne kitą techninị sprendimą - techninėmis galimybėmis, finansiniu, politiniu interesu ar ekologiniais motyvais, koks bus visų šių motyvų tarpusavio santykis? Ar, tarkime, Haffo energetinio kosmoso kolonizavimo idèja galètų būti vertinama kaip technikos medijuojamas tarpgeneracinis bendradarbiavimas: juk radus būdą išgauti energiją iš kosmoso, ja galima būtų aprūpinti ateities žmonių kartas? Tačiau ar nèra taip, kad tiek Andina’os, tiek Haffo pozicijos remiasi technikos etinio neutralumo prielaida, kurią Jonas kaip tik ir ginčijo? Ar tokiu būdu ateities kartos nepaverčiamos bendrininkèmis, mums nenorint užklausti savo elgesio prielaidų? Tad, mūsų manymu, čia tinkamesnis kitas - švedų aplinkosaugos aktyvistès Gretos Thunberg suburto globalaus judèjimo „Penktadieniai už ateiti““ - pavyzdys, šiuo atveju jaunimas ne tik radikaliai kritikuoja iškastinio kuro plètotès politiką bei palaiko atsinaujinančios energetikos idèją, bet ir pabrèžia būtinybę keisti vartotojišką gyvenimo būdą ${ }^{4}$.

Vis dèlto reikia pripažinti, kad iki šiol kalbėdami apie atsakomybès subjekto steigti pabrèžème savirefleksijos momentą ir viešųjų institucijų ịveiksminimo svarbą, tačiau nepakankamai atsižvelgeme ị techninès mediacijos specifiką, tai, jog ji komplikuoja moderniam mąstymui esmingą subjekto-objekto perskyrą, kurioje aktyvumas priskiriamas tik žmogiškam subjektui, o objektas - gamtinis ar techninis - visada lieka pasyvus. Pažymètina, kad vienas iš Haffo motyvų kalbèti apie technosferos autonomiją ir buvo suvokimas, jog technika nèra pasyvi. Pasak jo, žmogaus pastangoms apriboti vartojimą technosfera priešpriešina savo prevencinius gynybinius mechanizmus - paskatas, susijusias su maisto gausa, vaistais, greitos komunikacijos kanalais ir kitais trokštamais dalykais, kurie žmogų pririša ar netgi daro priklausomą nuo juos gaminančios sistemos (Haff 2018: 307). Todèl siekdami ịsigilinti $\mathfrak{i}$ techninès mediacijos pobūdị, $\mathfrak{i}$ tai, ar ir kiek pačioje technikos medijoje gali būti „irrašyti“ etiniai motyvai ir ar jie turi galios „pažadinti“ mūsų moralinę nuostatą, atidžiau panagrinèsime prancūzų filosofo, antropologo ir sociologo Bruno Latouro poziciją.

\section{Kvazi-subjektų ir kvazi-objektų tinklo steigtis}

Bruno Latouro santykis su kantiškaja etine tradicija yra kur kas komplikuotesnis nei mūsų jau aptarto Hanso Jonaso. Nors Latouras, panašiai kaip ir Jonas, pabrèžia ontologijos ir etikos sąsają, tačiau jis nesitenkina vien atsakomybès lauko išplètimu

4 Žr. Gretos Thunberg kalba Didžiosios Britanijos parlamente $2019 \mathrm{~m}$. balandžio 23 d. Prieiga per internetą: https://www.theguardian.com/environment/2019/apr/23/greta-thunberg-full-speech-to-mpsyou-did-not-act-in-time [žiūrèta 20207 21]; plg. Thunberg, G., Thunberg, S., Ernman, B., Ernman, M. 2019; Phoenix 2019. 
atsižvelgiant ị techninio veikimo mastą. Prancūzų mąstytojas teigia, jog turi būti peržiūrèta pati antropocentrizmo nuostata, kuria remiasi moderni ontologija, epistemologija ir etika. Veikale Egzistencijos būdų tyrinëjimas. Moderniuju antropologija Latouras nurodo būtinybę rinktis tarp „modernizavimo ir ekologizavimo“ (Latour 2013: 8), pastaraji t suvokdamas ne tik kaip ekologinès problematikos svarbos iškèlimą, bet ir kaip mąstymo prielaidų peržiūrējimą. Jis rašo:

Jei egzistuoju tik per kitą, kuris iš mūsų yra tikslas, o kuris priemonè? Kuo ilgesnè grandinè, tuo labiau šis klausimas neramina. Ypač dabar, kai ekologinès krizės paliečia daugybę nežmogiškų būtybių. Tas medis, ši žuvis, tie miškai, ši vieta, tas vabalas, šis genas, ta nuostabi dirva - ar jie yra mano tikslai, ar aš vèl turiu tapti jų tikslu? (Latour 2013: 455).

Pateiktoje citatoje iškeltas klausimas apie tikslą ir priemonę turètų būti suprantamas kaip klausimas apie subjektą ir objektą: sakydami, kad kažkas yra tikslas, suponuojame jo savaiminị pobūdị ir aktyvų veikimą, tuo tarpu objekto statusas reiškia priemonei būdingą pasyvumą ir inerciją, buvimą manipuliuojamu. Todèl galètume sakyti, kad subjekto-objekto perskyros persvarstymas veda prie etikos prielaiduc persvarstymo. Mat atsakomybès subjektas, arba, Latouro žodžiais, „moralinè būtybe““ steigiasi, kai užklausia savo kaip subjekto vienvaldišką padètị, kai persvarsto visus egzistuojančiuosius šio klausimo šviesoje. Būtent dvejonès ar skrupulo patirtis čia tampa etine patirtimi, ji yra „priešingybė tam, ką moralistai vadina „moraline pozicija“, dažnai vertinama dèl jos nesutaikomumo, dèl neatsitraukimo, dèl skrupulų neturèjimo“" (Latour 2013: 459). Latouras siūlo grịžti prie dvejonių dèl optimalaus tikslų ir priemonių paskirstymo:

Jei kiekvienas egzistuojantysis perdaro pasaulị savo būdu ir savo paties požiūriu, jo aukščiausia vertė, žinoma, yra jo egzistavimas remiantis juo pačiu, tačiau negali nekilti nerimas dèl to, kad kiti palikti šešèlyje vien kaip priemonès, daugybẻ kitų, kurie leidžia jam egzistuoti ir dèl kurių jis niekada nèra tikras, ar jie nèra jo tikslas. Žinoma, šis klausimas ne vien apie žmogiškas būtybes. Tik kantininkai palieka vargšui subjektui gniuždančią naštą tapti moraliu vietoje viso pasaulio, maža to - be pasaulio! (Latour 2013: 455-456)

Kanto etiniame antropocentrizme Latouras jžzelgia tendenciją paversti kitus esinius priemonėmis, kurią pats siekia ịveikti pereidamas nuo kontrolès paradigmos prie derybų paradigmos ${ }^{5}$. Pasak jo, buvimas subjektu reiškia ne autonomišką veikimą, o veikimą drauge su kitais subjektais, kurie taip pat nèra autonomiški: „Kai tik priartėjame prie nežmogiškų būtybių, nerandame jose inercijos, kuri leistų

5 Kai kuriuose veikaluose Latouras šią mintị plètoja kalbèdamas apie „daiktų parlamentą“ (Latour 2004 134-136; Latour 2014: 14-16). 
mums per priešpriešą joms laikyti save veikejjais (agents), bet, priešingai, aptinkame veikiančiuosius (agencies), kurie nèra atsieti nuo to, kas mes esame ir ką darome“ (Latour 2017: 62). Maža to, subjekto sąvoką Latouras linkęs pakeisti kvazi-subjekto sąvoka, kuri rodo atsitraukimą nuo autonomijos principo, mat pats žmogiškasis kvazi-subjektas randasi iš to, ką jis daro, jo kompetencija kyla iš pačios veiksmo atlikties, nèra jo turima iš anksto (Latour 2013: 230). Taigi subjekto-objekto perskyra čia persvarstoma atmetant tiek subjekto viešpatavimą, tiek objekto tapatinimą su fizikinių priežasčių nulemta forma.

Vis dèlto pažymètina, kad antropoceno problematikos kontekste subjektoobjekto perskyros komplikavimąsi (tiksliau - juvkkusị jos apvertimą) Latouras išsako pabrèždamas ne tik etikos, bet ir tragikos aspektą. Pasak jo, veikimas drauge su kitais subjektais antropoceno epochoje jau nebenumato harmonijos ar simbiozės, o veikiau karą, mat „žmogiškieji veikejjai gali pasirodyti scenoje pernelyg vélai, kad ką nors pataisytų... Visiškai apvertus labiausiai puoselètą Vakarų filosofijos tropą, žmonių visuomenès susitaikè su bežadžio objekto vaidmeniu, o gamta netikètai prisièmé aktyvaus subjekto vaidmenị! Tad tokia yra bauginanti „pasaulinio atšilimo“ prasmë“ (kursyvas B. L.) (Latour 2014: 11-12). Ši tragiškoji gaida nereiškia, jog ilgimasi prarastos vienvaldžio subjekto pozicijos, veikiau ji signalizuoja, koks pražūtingas yra susitapatinimas su neveiksnaus objekto lemtimi. Latouro manymu, antropoceno epochoje negelbsti nei vienvaldžio subjekto, nei pasyvaus objekto vaidmens prisiemimas, dabar turime imtis pasidalyto ir kuo ịvairiausiais būdais paskirstyto veikimo.

Todèl net jei kai kuriuose Latouro svarstymuose ir galime ižzvelgti savotišką etikos kaip pirmosios filosofijos variaciją - „Kai išstatai save kaip moralinę būtybę, viskas yra tavo, viskas tave liečia, tave neramina“ (Latour 2013: 461), - būtina pabrèžti, kad ji labiausiai domina „konkretus, kone techninis moralès èjimas“ (Latour 2013: 46). Kitaip sakant, moralumas jam turi objektyvų, empirinį, eksperimentinị, derybinị pobūdị, neatsiejamą nuo nuolaidų ir kompromiso, nuo susikompromitavimo, nes issipareigojama daugiau nei vienam kitam. Taip suprantamas moralumas nėra utilitaristinis visų ryšių apskaičiavimas, tačiau neapsiriboja lokalia gèrio ir blogio versija, jis netampa moralizavimu, nustatančiu ribas tam, kas svarbu / skaitosi, o kas nesvarbu / nesiskaito. Būtent šia - pasidalyto ir paskirstyto veikimo - prasme ir yra įdomus moralumo techninio medijavimo klausimas.

Manytume, kad ryškinant Latouro techninès mediacijos sampratoje aptinkamą moralumo delegavimo technikai momentą ${ }^{6}$, toliau būtų svarstoma ir Jonaso

6 Pakeitęs subjekto ir objekto sąvokas kur kas neutralesne semiotine aktanto sąvoka, Latouras kalba apie keturias technikos mediacijos prasmes: 1) atsakomybė už veiksmą turi būti padalyta tarp skirtingų aktantų; 2) veiksmas nèra žmonių, o aktantų asociacijos nuosavybė; 3) norédami suprasti technikos 
iškelta atsakomybės subjekto problema, tačiau ne vien apeliuojant ị kolektyviškumą viešosios politikos srityje, bet įtraukiant ị ši „kolektyvą" ir nežmogiškus esinius. Latouras parodé, jog sunkumas atskirti socialumą ir materialumą reikalauja atmesti griežtą subjekto-objekto skirtį ir kalbèti apie hibridinę tikrovę, kurioje gamtiniai reiškiniai yra kvazi-objektai, neatsiejami nuo žmogiškos veiklos pèdsako (pavyzdžiui, klimato šiltèjimas, ozono skylè, anglies dvideginis ir pan.), o kartu jie yra aktantai, savo ruožtu formuojantys kvazi-subjektus, t. y. darantys įtaką, išjudinantys politinius, etinius ir kitus sprendimu prièmimo procesus. Prisiminę anksčiau minètą atominès bombos pavyzdį, šioje perspektyvoje ji galetume traktuoti ir kaip pavyzdị kvazi-objekto, formuojančio žmogiškųjų kvazi-subjektų elgesį: atominès bombos griaunamosios galios dydis padaro neprasmingu šio ginklo panaudojimą ir paskatina sudaryti branduolinio ginklo neplatinimo sutartị, kuria branduolinị ginklą turinčios šalys ịsipareigoja jo neplatinti, naudoti branduolinę galią tik taikiais tikslais, pradèti nusiginklavimo procesą ir pan. Vis dèlto šiuo atveju etinis aspektas yra veikiau atsitiktinis, jis niekaip nepasirodo šio ginklo kūreję planuose. Todèl Latouro intenciją labiau atspindètų nuostata kurti tokias technologijas, $\mathfrak{i}$ kurių konstravimo procesą būtų sąmoningai ịtraukiami kvazi-subjektus formuojantys kvazi-objektai (Simons 2017: 14).

\section{Taromatas}

Siekdami detaliau aprašyti ar ir kiek pačioje technikos medijoje gali būti „îrašyti“ etiniai motyvai, pavyzdžiu pasirinkome Lietuvoje 2016 m. įdiegtą, prigijusią ir su plastiko tarša gana veiksmingai padedančią kovoti taromatų sistemą ${ }^{7}$, suteikiančią galimybę priduoti plastikines, stiklines ir metalines gẻrimų pakuotes atgaunant depozitą. Mūsų manymu, pasidalinto veikimo ir atsakomybès principas taromatu sistemoje ikūnytas sèkmingiau nei alternatyviuose technologiniuose projektuose, kur, pavyzdžiui, plastiko molekulių skaidymui planuojama pasitelkti genetiškai modifikuotus mikrobus ${ }^{8}$, mat taromatų sistema ne šiaip mažina plastiko taršą, bet palaipsniui keičia teršèjų elgesį̣. Taromatų sistemos pavyzdị rinkomès ir dèl to, kad

mediaciją, turime sąmoningai atidaryti techninès mediacijos ,juodąją dèžę ir pažvelgti ị tinklo dalis, kurios ją sudaro; 4) techninis veikimas yra delegavimo, perkèlimo forma (Latour 1994: 34-38).

7 Sistema apima 3000 taromatų, logistinius, teisinius, techninius sprendimus, susijusius su taros surinkimu ir jos perdirbimu. Plačiau žr. Platūkyte 2020.

8 Mikrobiologas Stephenas Techtmannas ir bioinžinierius Ting Lu planuoja sukurti sistemą, kuri leistų, pasitelkiant mikrobus ir šilumą, paversti plastiką baltymų milteliais (Christensen 2021). Gali būti, kad plastiko surinkimui būtų pasitelkti tie patys taromatai arba atliekų rūšiavimo konteineriai, tačiau pati mokslininkų siūloma inovacija labiau orientuota ị biocheminius procesus.

92019 metų gruodị USAD užsakymu „Spinter Research“ Lietuvoje atliktos apklausos duomenimis 85 proc. gyventojų, besinaudojančiu taromatų sistema, teigia, kad dalyvavimas užstato sistemoje juos paskatino rūšiuoti ir visas kitas atliekas (Platūkytè 2020). 2019 m. Europos Zero Waste 
jis atliepia Hanso Jonaso išskirtus technikos keliamus iššūkius - menką padarinių kontrolę, atsakomybės subjekto neapibrèžtumą - tačiau atliepia juos pačios techninès mediacijos priemonemis.

Taromatų, arba depozito grąžinimo, sistema turi priešistorę, kurią trumpai pristatysime, kad geriau išryškètų dabartinio jos pavidalo specifika ${ }^{10}$. Teigiama, kad daugkartinių gèrimų pakuočių grąžinimo sistema radosi Airijoje 1799-1800 m. Pradžioje kompanijos, pardavinejjusios gazuotą vandenị, pačios èmèsi iniciatyvos susigrąžinti panaudotą tarą. Pagrindine šios iniciatyvos priežastis ta, jog pagaminti naują butelị buvo kur kas brangiau nei panaudoti seną. Už tuziną grąžintų butelių buvo mokami 2 šilingai. Tais laikais tai buvo gana dideli pinigai, nes $1800 \mathrm{~m}$. vienas šilingas paprastai buvo mokamas už visos darbininko dienos darbą. Taigi daugkartinių pakuočių grąžinimo sistema radosi siekiant sumažinti gamybos kaštus. Galima sakyti, kad šiuo etapu motyvas - sutaupyti gamybos kaštus - transliuojamas su minimalia korekcija: i gamybos kaštų mažinimą ittraukiamas ir vartotojas, kuriam tokia sistema taip pat atrodo naudinga, tai skatina ji rinkti tarą, ją branginti, „padèti“ gamintojui, nes tik taip jis atgauna depozitą arba, jei ne jis buvo produkto pirkejjas, skatina jị tiesiog „užsidirbti“ pinigų. Taigi moralinių motyvų čia dar nesama, arba jų yra tik užuomazgos: susiduriame su naudos ar savanaudiškumo principu, $\mathfrak{i}$ kuri įtrauktas ir santykis su kitu, tačiau ne kaip kokia nors pareiga padèti kitam, o kaip bendradarbiavimą skatinantis to paties naudos principo pratęsimas. Panašiu principu veikusi sistema išplito ir jau valstybių lygmeniu galiojo ilgai. Produkto tara kartais sudarydavo iki pusès paties produkto kainos, tad akivaizdu, kad buvo vertinamos žaliavos, t. y. pati pakuotė, kurią be didesnių problemų galima naudoti daug kartų. Ekologiniai motyvai pradžioje iš viso nepasirodè, juos galima priskirti tik atgaline tvarka, iš dabartinès situacijos perspektyvos.

Daugkartinès taros grąžinimas ilgą laiką vyko rankiniu būdu, nors pirmoji butelių grąžinimo mašina buvo užpatentuota JAV dar 1920 m. (Elmerio M. Joneso ir Sue Walkerio Vance’o); veikianti mašina pasirodè XX a. 6 dešimtmečio pabaigoje Švedijoje (sukurta kompanijos „Wicanders“), o visiškai automatizuota 1962 m. Norvegijoje.

1971 m. žymi užstato sistemos virsmą, mat tais metais pradejo veikti vienkartinių gèrimų pakuočių užstato sistema, sukurta jau ịtraukiant ir aplinkosauginị motyvą. Vienkartinių pakuočių antrą kartą lengvai nepanaudosi, todèl jų perdirbimui buvo reikalingas kur kas platesnès sistemos sukūrimas. Viena pirmụjų tokio

organizacijos Taromatų sistemos manifesto septintasis punktas skelbia, jog ši sistema yra naudingas ịrankis, padedantis piliečiams vizualizuoti savo veiksmų poveikį, o tai sustiprina etinę motyvaciją (prieiga per internetą: https://www.reloopplatform.org/zero-waste-europe-releases-drs-manifesto/ [žiürèta 20210730 ).

${ }^{10} \mathrm{Plg}$. žr. https://en.wikipedia.org/wiki/Container-deposit_legislation [žiūrèta 202106 28]. 
pobūdžio sistemų pradejjo veikti JAV Oregono valstijoje, Europoje šioje srityje lyderiavo Švedija - 1984 m. čia ị užstato sistemą buvo ịtrauktos aliuminio skardinès, 1994 m. - plastikiniai buteliai. Tačiau svarbu pabrèžti, kad atsiradusi taromatų sistema ne papildè ligi tol gyvavusios užstato sistemos tikslą papildomais aplinkosauginiais tikslais, kaip antai paskatinti perdirbimą ir sumažinti energijos bei materialinių išteklių naudojimą taros gamybai, sumažinti šiukšlių kiekị pakelèse, prie ežerų, upių bei kitose viešose ir privačiose teritorijose, prailginti užkasamų sąvartynų gyvavimą, bet veikiau „išvertè“ tikslą „priduoti pakuotes, kad būtų sumažinta aplinkos tarša “ $\mathfrak{i}$ tikslą „priduoti pakuotes, kad atgautum depozitą“. Pirmoji jo versija apeliuoja ị moralę, nesuinteresuotumą ir refleksiją, o antroji ị savanaudiškumą. Tad greičiausiai galima daryti išvadą, kad su taromatų sistemos įdiegimu išaugęs pakuočiu surinkimo kiekis Lietuvoje rodo, jog daugybe žmonių atliepia antrą, o ne pirmą tikslą: savanaudiškumas yra plačiau paplitusi savybẻ nei rūpestis aplinka.

Taip pat reikia pasakyti, kad moralumo delegavimas technikai nereiškia vien moralumo perkèlimo iš diskurso ị materiją, tai sykiu yra perkèlimas ị kitą laiką, erdvę ir veikèją. Pasitelkiant Latouro vartojamus semiotikos terminus, galima sakyti, kad aplinkosauginio diskurso aktantinę struktūrą, kurią sudaro adresantas (gamtosauginis imperatyvas, reikalaujantis surinkti pakuotes, kad būtų sumažinta aplinkos tarša), adresatas (produktų vartotojas) ir vertės objektas (švari aplinka) papildo naujas aktantas - taromatas (tiksliau, platus taromatų tinklas), kuris paskatina mus surinkti metalo ir plastiko pakuotes, papildydamas etinį motyvą naudos principu. Taromato medijavimas suproblemina vertès objektą (švari aplinka? depozitas?) sykiu sukompromituodamas ir etinio motyvo grynumą. Vis deltto Latourui veikiausiai čia būtų svarbesnis pasidalytas veikimas: aplinkos taršą sumažinti padedantis naujas aktantas laiko prasme gyvuoja jau keletą dešimtmečių, nors šio techninio veiksmo adresantai (inžinieriai) pasitraukè nuo scenos. Taigi galime stebèti akumuliuojantị taromatų veikimo efektą, kaip simetrišką atsaką aplinkos taršos akumuliacijai: surenkama vis daugiau panaudotų pakuočių pasinaudojant taip pat ir savanaudiškais motyvais, kone refleksiniu veikimu, kuriam nebūtinas nuostatos keitimas, gal tik naujo ịpročio suformavimas.

Pritardami Latourui, kad mūsų elgesys yra mūsų intencijų ir technikos mediacijos sąveikos rezultatas, vis dèlto norime kreipti $\mathfrak{i}$ klausimus, kuriuos kelia pasitelktas taromato sistemos pavyzdys. Ką taromato sistemos atveju reiškia optimalus tikslų ir priemonių paskirstymas? Kiek svarbu, kad tikslas - surinkti daugiau panaudotų pakuočių, taip sumažinant aplinkos taršą - būtų atpažistamas? Ar jis gali likti tik techninio veiksmo sakytoju - inžinierių - intencija? Ar, neatpažindami jo, depozito grąžinimo žaidimą galètume atskirti nuo prekybos tinkluose rinkodaros tikslais pasitelkto lipdukų ar kokių nors taršių niekučių rinkimo žaidimo? 
Ir, jei minèto tikslo neatpažistame, ar galime sakyti, kad formuojasi atsakomybès kvazi-subjektas? Pagaliau, ar technikos mediacija nekelia rizikos pačiai etikai būti redukuotai ị instrumentinio sprendimo paiešką?

I šiuos klausimus nèra lengva atsakyti. Latouras kalba apie techninę mediaciją kaip vertimą, t. y. pakeitimą, perkèlimą, nukrypimą, išradimą, sukūrimą sąsajos, kurios iki tol nebuvo ir kuri tam tikru laipsniu modifikuoja veikejjus, kurie apsikeičia savo savybėmis (Latour 1994: 32-33, 38-39). Čia negalime tikètis išgrynintos etinès intencijos. Tačiau techninè mediacija sykiu yra nelyg akla dèmè ar „juoda dèžè, kurią Latouras moko atidaryti. Tada taromatas pasirodo kaip pilnas inžinierių, gamtosaugininkų, teisèkūros atstovų, verslininkų, jų valių ir pasakojimų, susimaišiusių su plastiko, geležies, stiklo, dažų ir standartinių skaičiavimų pasakojimais. Galima sakyti, kad tik atidarius „juodąją děžę“ pamatoma, kad banalus pakuotès pridavimo veiksmas talpina skirtingus pasakojimus: 1) gamtosaugininkai siekia sumažinti taršą, jiems rūpi ne pati depozito surinkimo sistema, o išmestų pakuočių surinkimas; 2) gamintojai ir gèrimų importuotojai siekia naudos, tačiau sutinka mokèti subsidijas už savo pačių pakuočių sutvarkymą, užuot vaikęsi galimybès pigiausiai parduoti savo produkciją; 3) teisèkūros atstovai ịtvirtina teisės aktuose principą „teršèjas moka“; 4) inžinieriai kuria ir tobulina taros pridavimo mechanizmą atsižvelgdami î pasitaikančius sukčiavimo atvejus; 5) plastikas, geležis, aliuminis, stiklas - medžiagos, panaudotos tiek taros, tiek paties taromato gamybai - jų kiekis, ilgaamžiškumas, „elgesys“ ìveiksminami taromatų sistemoje.

Latouro manymu, technikos medijavimas steigia „kolektyvą“, kuriam būdingas apsikeitimas žmogiškomis ir nežmogiškomis savybèmis bendro kūno viduje, jame viskas turi būti kiek įmanoma sujungta, nors viskas yra nepalyginama ir nebendramatiška. Jis ragina sąmoningai atidaryti ,juodąją dèžę “ ir įsižiūrèti ị techninę mediaciją sudarančio tinklo dalis. Tada pamatome, kaip technikos medijuojamas etinis motyvas buvo ịrašytas ị ilgų veiksmo grandinių sampyną, kurios dèka tolimoje praeityje ir nutolusioje vietoje, atliktas veikejų, kurių dabar nėra, veiksmas tampa dabartiškas, su sąlyga, kad jis yra perkeltas, išverstas, deleguotas kitų tipų aktantams, vadinamiesiems nežmonèms.

Vis dèlto neapleidžia abejonès dèl techninei mediacijai deleguoto etinio motyvo atpažinimo: ar gali būti, kad ilgainiui jis gali tapti neatpažǐstamas, panašiai kaip Homero Odisejjo ant peties nešamas irklas, kuris žmonèms, nemačiusiems jūros, gali pasirodyti esąs vètyklè $\dot{1}^{11}$ ?

${ }^{11}$ Latouras pats imasi palyginimo su Odisejo klajonèmis, tačiau kita prasme - jo manymu, esame filosofijos istorijos pasmerkti ilgoms klajonèms, kol neišsitrinsianti subjekto-objekto skirtis (Latour 2014: 15-16). 


\section{Išvados}

Siekeme parodyti, kad gresiant globaliai ekologinei krizei atsakomybès subjekto steigtis vyksta įtampoje tarp dviejų perspektyvų - globalios ir lokalios, o technikos mediacija šiame procese yra ne tik problemos, bet ir sprendimo dalis. Lyginant Hanso Jonaso ir Bruno Latouro pozicijas, išryškejjo ne vien dviejų technikos filosofų strategiju priešprieša: Jonaso, kreipiančio ị sąmoningą askezę ir techninės galios kontrolę, ir Latouro, puoselejjančio hibridinių subjektų daugio pasidalintą veikimą. Manytume, kad kur kas svarbiau tai, jog technikos medijuota atsakingo subjekto steigtis abiejų mąstytojų aprašoma pabrèžiant atsakomybès už kitą momentą: tiek „baimès euristikos“ praktika, tiek „juodosios dèžès“ efekto panaikinimas steigia maksimaliai ir globaliai atsakingą būvị - atsakomybę už ateities žmonių kartas ir atsakomybę už gamtinius-techninius hibridus. Pažymètina, kad žmogaus techninès galios sukeliamų padarinių masto įsisąmoninimas veda prie subjekto autonomija grindžiamo modernybès mąstymo kritikos. Gretinant abiejų filosofų pastangas apibrèžti savąją poziciją per santykị su Kanto etine mintimi, išryškeejo tendencija „ipasaulinti“, „ižeminti“ etinę motyvaciją užuot siekus jos grynumo. Straipsnyje pasitelktas taromatų sistemos pavyzdys parodé, kaip etinè motyvacija gali būti „ịrašyta" technikos medijoje, kuri akumuliuojantị technikos efektą, susiejantị lokalią ir globalią perspektyvas, panaudoja gamtosauginiais tikslais. Viena vertus, matome, kad platus taromatų tinklas leidžia susiburti gausiam „kolektyvui“, apimančiam tiek žmogiškus, tiek nežmogiškus veikiančiuosius, kurie prisideda mažinant plastiko taršą, tačiau, kita vertus, techninès mediacijos analizei pasitelktoje Latouro pasiūlytoje perspektyvoje išnyksta griežta etinio ir techninio sprendimų skirtis, o tai leidžia teigti, kad etinis sprendimas jau „užterštas“ techninio sprendimo, iškreipiančio pirminę motyvaciją, kaip ir techninis sprendimas jau paženklintas etinio sprendimo pèdsako.

Gauta: 2021-08-01

Priimta: 2021-09-30

\section{Literatūra}

Andina, T. 2018. “Transgenerational actions and responsibility", Journal of Critical Realism, 17 (4): 364-373. Prieiga per internetą: https://www.tandfonline.com/doi/full/10.1080/ 14767430.2018.1488204 [žiūrèta 20210721 ].

Andina, T. 2021. „Realistinès prieigos taikymo klimato problemai klausimu: transgeneracinès atsakomybès principas, in Sabolius, K. (sud.). Apie tikrovę. Vilnius: Lapas, p. 329-330.

Beck, U. 1995. Ecological Politics in an Age of Risk, translated by A. Weisz. Cambridge: Polity Press.

Beck, U. 2000. "Risk Society Revisited: Theory, Politics and Research Programmes", in Adam, B., Beck, U., Loon, J. (eds.). The Risk Society and Beyond. Critical Issues for Social Theory. London: Thousand Oaks, New Delhi: Sage Publications, p. 211-229. 
Beck, U. 2009. World at Risk, translated by C. Cronin. Cambridge. Cambridge: Polity Press.

Chakrabarty, D. 2018. "Anthropocene Time", History and Theory, 57 (1): 5-32. DOI: 10.1111/ hith.12044

Christensen, K. 2021. " $€ 1$ Million Prize for Plastics-to-Protein Research Awarded to Steve Techtmann, Ting Lu”, Michigan Tech News. Prieiga per internetą: https://www.mtu.edu/ news/2021/07/1-million-prize-for-plasticstoprotein-research-awarded-to-steve-techtmann-ting-lu.html [žiūrèta 202107 30].

Clark, T. 2012. "Derangements of Scale", in Cohen, Th. (Ed.). Telemorphosis. Theory in the Era of Climate Change. Volume I. Open Humanities Press, p. 148-166.

De Preester, H. 2021. "Subjectivity and Transcendental Illusions in the Anthropocene", Foundations of Science. Prieiga per internetą: https://doi.org/10.1007/s10699-02009733-6 [žiūrèta 202109 19].

Haff, P. K. 2014. "Technology as a Geological Phenomenon: Implications for Human WellBeing", in Waters, C. N., Zalasiewicz, J. A., Williams, M., Ellis, M. A. \& Snelling, A. M. (eds.). A Stratigraphical Basis for the Anthropocene. London: Geological Society, Special Publications, 395 (1): 301-309, http://dx.doi.org/10.1144/SP395.4 .

Hamilton, C. 2015. "The Banality of Ethics in the Anthropocene", The Conversation, 201507 13. Prieiga per internetą: https://theconversation.com/the-banality-of-ethics-in-the-anthropocene-part-1-44568 [žiūrèta 202105 16].

Hamilton, C., Bonneuil, Ch., Gemenne, F. 2015. "Thinking the Anthropocene", in Hamilton, C., Bonneuil, Ch. Gemenne, F. (eds.). The Anthropocene and the Global Environmental Crisis. Rethinking Modernity in a New Epoch. London: Routledge, p. 1-13.

Hui, Y. 2021. "For a Cosmotechnical Event", Foundations of Science. Prieiga per internetą: https://link.springer.com/article/10.1007/s10699-020-09740-7

Hui, Y. 2016. The Question Concerning Technology in China: An Essay in Cosmotechnics. UK: Urbanomic.

Jonas, H. 1984. The Imperative of Responsibility. In Search of an Ethics for Technological Age. Translated by H. Jonas with the collaboration of D. Herr. Chicago and London: The University of Chicago Press.

Jonas, H. 1996. "Toward an Ontological Grounding of an Ethics for the Future", in Jonas, H. Mortality and Morality: A Search for the Good after Auschwitz. Evanston, Illinois: Northwestern University Press, p. 99-112.

Kantas, I. 1991. Sprendimo galios kritika, verte R. Plečkaitis. Vilnius: Mintis.

Latour, B. 1994. „On Technical Mediation - Philosophy, Sociology, Genealogy“, Common Knowledge, 3 (2): 29-64.

Latour, B. 2004. Mes niekada nebuvome modernūs. Simetrinés antropologijos esé, vertè N. Vyšniauskaite. Vilnius: Homo liber.

Latour, B. 2013. An Inquiry into Modes of Existence. An Anthropology of the Moderns. Translated by Catherine Porter. Cambridge, Massachusetts London, England: Harvard University Press.

Latour, Bruno. 2014. "Agency at the Time of the Anthropocene." New Literary History: A Journal of Theory and Interpretation 45(1): 1-18. https://doi.org/10.1353/nlh.2014.0003

Latour, Bruno. 2017. Facing Gaia. Eight Lectures on the New Climatic Regime. Translated by C. Porter. Cambridge, UK; Malden, MA: Polity Press.

Lemmens, P., Blok, V., Zwier, J. 2017. "Toward a Terrestrial Turn in Philosophy of Technology", Techné: Research in Philosophy and Technology, 21 (2-3): 114-126. DOI: 10.5840/techne2017212/363

Lemmens, P., Van Den Eede, Y. 2021. "Rethinking Technology in the Anthropocene: Guest Editors' Introduction", Foundations of Science. Prieiga per internetą: https://doi. org/10.1007/s10699-020-09772-z [žiūrèta 202109 20].

Lifton, R. J., Markusen, E. 1991. The Genocidal Mentality: Nazi Holocaust and Nuclear Threat. London and New York: Macmillan.

Phoenix, A. 2019. "'Greta Thunberg effect' and how ordinary families feel about climate change", Transforming Society, 201909 27. Prieiga per internetą: https://www. 
transformingsociety.co.uk/2019/09/27/the-greta-thunberg-effect-and-how-ordinaryfamilies-feel-about-climate-change/ [žiūrèta 202107 21].

Platūkytė, D. 2020. „Dèl taromatų Lietuvai skrieja pagyros iš viso pasaulio, o šalys prašo patarimų: ko mums trūksta iki maksimalaus rezultato?“, lrt.lt. Prieiga per internetą: https://www.lrt.lt/naujienos/verslas/4/1193381/del-taromatu-lietuvai-skrieja-pagyrosis-viso-pasaulio-o-salys-praso-patarimu-ko-mums-truksta-iki-maksimalaus-rezultato [žiūrèta 20210721 ].

Simons, M. 2017. “The Parliament of Things and the Anthropocene: How to Listen to 'QuasiObjects"', Techné: Research in Philosophy and Technology, 21 (2-3): 1-25.

Stiegler, B. 2018. The Neganthropocene. Translated by D. Ross. London: Open Humanity Press. Stroud, S. R. 2003. "Living Large: Kant and the Sublimity of Technology", Teaching Ethics, Fall 2003, p. 47-67.

Thunberg, G., Thunberg, S. Ernman, B., Ernman, M. 2019. Lyg degtu namai. Mūsu kova su klimato kaita, vertè E. Voidogienè. Vilnius: Alma littera.

\section{Danutè Bacevičiūtè}

\section{CONSTITUTION OF THE SUBJECT OF RESPONSIBILITY IN THE AGE OF TECHNOLOGY: HANS JONAS AND BRUNO LATOUR}

\section{Summary}

This article opposes the attempts to marginalize ethical issues and defend the thesis of technosphere as an autonomous phenomenon in the Anthropocene. The author points out that by evading the question of ethical perspective and responsibility, the technological activity and its trace are naturalised, and any ethical decision is therefore turned into a technical decision. The comparison of the positions of two philosophers of technology (Hans Jonas and Bruno Latour) enables us to reflect on how technology mediates the constitution of the subject of responsibility in the tension of global and local perspectives. The article shows that Jonas' "heuristics of fear" leads to the conscious practice of asceticism and the collective control of technical power, while Latour leaves open a possibility of talking about the shared action of a multitude of hybrid actors, in which both the ethical solution is already "contaminated" with the technical and the technical solution retains the trace of the ethical. By using the example of the reverse vending machine, it is shown how ethical motivation is inscribed into technical media, which uses the technological accumulation to link global and local perspectives for environmental purposes.

KEYWORDS: Anthropocene, technical mediation, responsibility, quasi-subject, quasi-object, Hans Jonas, Bruno Latour. 